Trinity University

Digital Commons @ Trinity

Health Care Administration Faculty Research

Health Care Administration

Fall 1997

\title{
Relative Wages and Exit Behavior Among Registered Nurses
}

Edward J. Schumacher

TrinityUniversity, eschumac@trinity.edu

Follow this and additional works at: https://digitalcommons.trinity.edu/hca_faculty

Part of the Medicine and Health Sciences Commons

\section{Repository Citation}

Schumacher, E.J. (1997). Relative wages and exit behavior among registered nurses. Journal of Labor Research, 18(4), 581-592. doi: $10.1007 / \mathrm{s} 12122-997-1024-5$

This Article is brought to you for free and open access by the Health Care Administration at Digital Commons @ Trinity. It has been accepted for inclusion in Health Care Administration Faculty Research by an authorized administrator of Digital Commons @ Trinity. For more information, please contact jcostanz@trinity.edu. 


\title{
Relative Wages and Exit Behavior among Registered Nurses*
}

\author{
EDWARD J. SCHUMACHER \\ East Carolina University, Greenville, NC 27858
}

I examine the exit decision of registered nurses using the longitudinal data files generated by the March Current Population Surveys (CPS) from 1983 through 1994. By examining the wages of workers outside of nursing, a measure of the reservation wage is constructed and related to the decision to leave nursing, either for an alternative job or to exit employment. My results indicate that nurses respond to outside wage opportunities. A one standard deviation decrease in the difference between the actual and predicted log wage results in an 8 percent increase in the exit of nurses. Secretaries, however, are shown to have a much greater sensitivity to outside wages due to the lower degree of occupation-specific training required for secretarial jobs. A similar increase in the wage gap for secretaries results in an 18 percent increase in turnover. RNs employed in hospitals, covered by a union contract, and employed in the public sector are relatively attached to the nursing profession.

\section{Introduction}

The labor market for registered nurses has received considerable attention from both researchers and health care policy makers. During the 1980s there were frequent reports of nursing shortages even though $\mathrm{RN}$ wages were rising considerably faster than wages economy-wide. Recently, as the growth in health care expenditures has slowed, RN's real and relative wages have fallen (Schumacher, forthcoming). As a result, entry-level enrollments in nursing schools declined for the 1995-96 academic year for the first time in six years, and new RNs are taking longer to find employment (Brider, 1996b). While the growing trend of moving care out of the hospital into more cost-effective settings and other cost containment measures are expected to affect the demand for RNs less than for other health care professionals, it is expected that the demand for RNs will continue to decline (Brider, 1996a).

These factors lead to questions concerning the supply response of registered nurses to market changes and relative wages. There have been several studies explicitly measuring the labor supply schedule among registered nurses (Link, 1992; Link and Settle, 1981a, 1981b, 1979; Phillips, 1996). I am aware of only one study which examines factors influencing the decision of RNs to exit the labor market: Parker and Rickman (1995) find that married RNs are more likely to withdraw from the labor force than unmarried RNs, while spouses' income is not an important determinant of 
labor force withdrawal. Parker and Rickman, however, do not consider altemative wages, do not analyze the decision to switch into an altemative occupation, and do not examine the issue of measurement error in their data.

My study examines occupational mobility among registered nurses. Using quasi-panels constructed from current and retrospective questions included in the March Current Population Surveys, I conduct a longitudinal analysis of flows into and out of the registered nursing labor market during the 1983 to 1994 period. The decision to exit nursing is related to an estimate of the expected wage if employed in altemative occupations. Nursing occupations require a high degree of occupationspecific training and RNs (once trained) are likely to be relatively immobile across occupations and not overly sensitive to outside wages. A greater sensitivity to outside wages is likely in occupations where less specific training is required. I test this hypothesis by comparing RNs to secretaries. The results indicate that nurses are somewhat responsive to their relative wage, although secretaries are substantially more sensitive to outside wages. The analysis not only informs us about the functioning of nursing labor markets, but provides a useful case study of tumover and occupational choices among professionals.

\section{Employment Flows}

The Data. My primary data are from the March Current Population Survey (CPS) and the March-June CPS outgoing rotation group files for the years 1983 through 1994. The CPS is the primary U.S. household survey conducted monthly by the Bureau of the Census. The CPS sample design is such that households are included in 8 surveys (rotation groups), beginning with 4 consecutive months in, followed by 8 months out, followed by 4 months in. Outgoing rotation groups (ORGs) 4 and 8 are asked eamings supplement questions (weekly earnings, hours, union status, etc.). The March surveys include a supplement that provides retrospective information (for all rotation groups) on each worker's employment in the year prior to the survey, including the number of employers in the previous year and the longest occupation and industry from the previous year. The supplements also contain information on total earnings (from all jobs) last year, total weeks worked, and usual hours worked per week, allowing a measure of hourly earnings in the previous year to be constructed. The March surveys contain information on current eamings (on the primary job) and employment for a quarter of the sample (the outgoing rotation groups). Those who were not outgoing in March are outgoing in either April, May, or June and would report their current earnings, hours, and other variables in these months. By matching the March surveys with the ORGs for the months of March, April, May, and June, a (nearly) full sample of all March rotation groups is attained, containing labor market information for both the current and previous years. ${ }^{1}$

The March supplements are constructed from a single survey, and miscoding or misreporting is relatively unlikely since the data are gathered at one point in time and utilize a single Census coder. Alternatively, longitudinal data from matched ORG 
files tend to overstate occupational change (Polivka and Rothgeb, 1993). As a check on transition rates, however, data from the Sample Survey of Registered Nurses (SSRN) for 1984, 1988, and 1992 are also utilized. This survey is conducted by the U.S. Department of Health and Human Services, Public Health Services, Health Resource and Services Administration. The data, obtained from a mail survey of a sample of licensed registered nurses, contain roughly 30,000 observations per year, yielding large samples of RNs (including those employed in or out of nursing, unemployed, or out of the labor force). The survey asks if the individual was employed in nursing the previous year, allowing separate measures of the numbers of joiners and leavers. The SSRN, however, does not ask eamings or other employment characteristics from the previous year.

Employment Flows. Table 1 presents the major employment flows and mean characteristics for RNs from the CPS and the SSRN. Of the 11,003 individuals employed as RNs in year 1 (i.e., the primary job the previous year), 93.0 percent of them are also employed in year 2 (in March-June). According to the SSRN data, 95.8 of the individuals employed as RNs in the first year are also employed as RNs in the subsequent year. The difference in these numbers appears almost exclusively in the number of those moving to other occupations (switchers). The CPS data report about 3 percent of those employed in the first year are employed in an alternative occupation in the second year, while the SSRN suggest that this is the case for only about 1 percent of the sample. Both data sources yield similar numbers of individuals withdrawing from employment (quitters). The CPS measure of occupation is self reported (individuals describe their job duties, and Census coders place them in one of about 500 occupational categories), whereas the SSRN is mailed only to licensed RNs. The CPS is likely to contain a broader range of individuals whose occupation is classified as RN. Thus, if individuals misreport their longest occupation last year, but accurately report their current occupation (or vice versa), they are coded as leavers (or joiners).

Among those reporting their occupation as $\mathrm{RN}$ in the second year, about 4.3 percent join from another occupation and 1.1 percent enter the labor force. The SSRN data do not distinguish those entering the labor force from those entering from another occupation, but the total percentage of joiners is similar to that from the CPS data. The CPS data suggest that the join rate among RNs is about 5.4 percent while the exit rate is about 7.0 percent. RN employment increased consistently over the period (Schumacher, forthcoming), so the lower join than exit rate is puzzling. The low join rate is due to the nature of the March surveys. Individuals report their longest occupation held last year. In order to be considered a joiner, RNs are required to report an occupation other than registered nursing or not be employed during the year. A typical pattern, however, is for new entrants to finish schooling in early summer and find a job beginning late in the year. When such entrants are interviewed the following March, they report their longest occupation last year as RN and are not counted as joiners. The SSRN data show a join rate of 6.3 percent and an exit rate of 4.2 percent. $^{2}$ The March data on entry, therefore, understate the extent of new entrants in the market, and the analysis below is restricted to exit behavior. 
Table 1

Employment Flows for RNs

\begin{tabular}{lcr}
\hline & Employed RNs in Year 1 & \\
\hline Status in Year 2 & March CPS & SSRN \\
Employed as RNs & 0.930 & 0.958 \\
$\quad$ Age & 38.91 & 40.65 \\
Married & 0.68 & 0.71 \\
Real Wage & 16.29 & 18.01 \\
$n$ & 10,235 & 73.915 \\
& & \\
Employed Elsewhere & .033 & 0.009 \\
Age & 37.06 & 40.33 \\
Married & 0.61 & 0.70 \\
Real Wage & 11.69 & - \\
$n$ & 360 & 696 \\
& & \\
Not Employed & 0.036 & 0.033 \\
Age & 43.57 & 0.78 \\
Married & 0.76 & 2.584 \\
Real Wage & $-\overline{6}$ & \\
$n$ & 408 &
\end{tabular}

Employed RNs in Year 2

\begin{tabular}{lcr}
\hline Status in Year 1 & March CPS & SSRN \\
Employed as RNs & 0.946 & 0.937 \\
Age & 38.91 & 40.65 \\
Married & 0.68 & 0.71 \\
Real Wage & 17.66 & - \\
$n$ & 10,235 & 73,915 \\
\hline Employed Elsewhere & 0.043 & - \\
Age & 39.13 & - \\
Married & 0.61 & - \\
Real Wage & 14.85 & - \\
$n$ & 469 & - \\
\hline Not Employed & & - \\
Age & 0.011 & - \\
Married & 36.92 & - \\
Real Wage & 0.58 & - \\
$n$ & - & \\
\hline
\end{tabular}

Note: Data are from the March CPS supplements for years 1983-1994, and the Sample Survey of Registered Nurses for 1984, 1988, and 1992. Characteristics in the top panel are for the second year, and those in the bottom panel are for the first year. 


\section{The Predicted Wage and the Decision to Exit}

In a careful study of the labor supply response of registered nurses, Link (1992) models hours worked, controlling for selectivity through the initial estimation of a labor force participation probit model for the years 1960, 1970, 1977, 1980, 1984, and 1988. His results support previous findings that the own-wage elasticity for married nurses was quite high in 1960, but after 1960 the elasticity estimates are relatively low (the results are highly variable though, from a low of -0.19 in 1970 to a high of 0.43 in 1984). The own-wage elasticity on hours worked is lower for unmarried than for married RNs.

Link's results suggest that RNs are not highly sensitive to the real wage and that wage increases are unlikely to provide a low cost way of attracting greater hours from the stock of currently employed RNs. His analysis first considers the nurse's decision (once trained) to either participate in the RN market and then, given the decision to participate, estimates how sensitive RNs are to their real wage. My analysis asks a different, but related, question. It relates the decision to leave nursing to the relative wage of the individual nurse.

Information from the CPS on alternative occupations is utilized to measure how the relative wage influences the exit decision of nurses. First, a predicted wage based on a log-wage regression conducted on a control group of workers is constructed. This group consists of females with at least two years of college in the following broad occupational categories (with health occupations excluded): professional specialty occupations; technicians and related support; sales, administrative support, and clerical; and service occupations (except protective and household services). This regression includes years of schooling, potential experience (the minimum of age school -6 and age -16 ) and higher order terms to the fourth power, and dummies for race (2), Hispanic origin, large metropolitan area, part-time status, union coverage, region (8), marital status (2), public employment, and year (11). The coefficients from this regression are then used to construct a predicted wage for RNs, providing an estimate of what the nurse would earn if she were employed outside of nursing. The "External Gap" is defined as the difference between the actual log real wage and the predicted log real wage in the analysis below. As an alternative measure, a similar regression is run for a registered nurse sample (including an additional dummy variables for hospital employment and gender). The "Internal Gap" is calculated as the actual log real wage minus the RN predicted log real wage and is intended to capture within nursing relative wages. The use of both measures allows a test of the sensitivity of the two wage structures on the exit decision of RNs. ${ }^{3}$

Assuming that variables included in the wage regression fully measure human capital and other wage determinants, comparing a nurse's actual wage to her predicted wage potentially provides a measure of whether the nurse is being "underpaid" or "overpaid." If there are significant unmeasured worker quality measures then individuals who are designated as overpaid could be high (unmeasured) quality, while those who are designated as underpaid may be low quality workers. My esti- 
mates, therefore, are likely to understate the true responsiveness to outside wages. For example, if all RNs are paid exactly their opportunity cost wage, turnover will not vary with measured differences in actual and predicted wages.

An important issue in occupational mobility is the relative ease of skill transfer. $\mathrm{RN}$ training tends to be quite specific, and the transfer of these skills to other occupations is difficult. This is supported by the relatively few number of occupational switchers found in Table 1. The less transferable a worker's skills the less sensitive he or she is to outside opportunities (once the skills have been obtained). I examine this directly by comparing the responsiveness of RNs to the wage gap to the responsiveness of secretaries - an occupation where training is more easily transferred.

The Decision to Exit. If nurses are sensitive to relative wages, and the error in the predicted wage is a good measure of over- and underpayment, the smaller is the wage gap the more likely they will be to exit nursing. If nurses are not concerned with outside opportunities or they are not sufficiently mobile to consider these opportunities, then the exit decision and the predicted wage should be uncorrelated. Table 2 displays the mean for both the external and internal wage gap measures by age, for RN stayers, switchers, and quitters. The actual wage is higher than the control group predicted wage for all three groups, but it is larger for RN stayers than both RN switchers and quitters. This is most apparent for young RNs. When the RN wage gap is used, stayers have a higher residual than switchers, but not quitters. These results suggest that the decision to leave nursing is correlated with the relative wage of the worker. ${ }^{4}$

To understand more explicitly the exit decision of RNs, a multinomial logit model is estimated to determine the major factors influencing a nurse's decision to leave the occupation. I model the decision to exit as a function, not only of personal characteristics, but also of the estimated relative payoff from leaving nursing. Table 3 presents the multinomial logit coefficient estimates for changing occupation and leaving employment, with staying in nursing being the omitted reference category. The first number in each cell is the coefficient estimate, the second number (in parenthesis) is the $t$-statistic for this estimate, and the third number (in brackets) is the marginal effect of the independent variable on the probability of leaving for another occupation or quitting the labor market (computed at the means of all the other $\mathrm{Xs}$ ). Many of the marginal effects are statistically significant, although most have small magnitudes on the probability of a particular employment state. This is due in large part to the fact that only a small percentage of the sample leaves. Only 3.3 percent switch and 3.7 percent quit, leaving little variation in the data to explain. ${ }^{5}$

Table 3 shows the results of estimating the model with both measures of the wage residual. ${ }^{6}$ The wage gaps have an insignificant (though negative in magnitude) impact on the decision of an RN to leave employment. Both the internal and external gap, however, indicate that the decision to leave nursing for another occupation is influenced by the alternative wage. Though the magnitude of the impact is small, the larger difference between the RNs actual wage and predicted wage, the less likely the $\mathrm{RN}$ is to leave nursing. A one standard deviation (0.42) increase in the external gap 
Table 2

Mean Predicted Wage Residual by Employment Status and Age Group

\begin{tabular}{lrrrr}
\hline & ALL & Age 20-35 & Age 36-50 & Age > 50 \\
\hline Stayers & & & & \\
$\quad$ External Gap & 0.394 & 0.448 & 0.360 & 0.344 \\
$\quad$ Internal Gap & 0.027 & 0.029 & 0.020 & 0.042 \\
$\quad n$ & 10,235 & 4,329 & 4,309 & 1,597 \\
Switchers & & & & \\
$\quad$ External Gap & 0.271 & 0.256 & 0.270 & 0.318 \\
$\quad$ Internal Gap & -0.057 & -0.121 & -0.028 & -0.037 \\
$\quad n$ & 360 & 150 & 157 & 53 \\
Quitters & & & & \\
$\quad$ External Gap & 0.338 & 0.322 & 0.316 & 0.369 \\
Internal Gap & 0.075 & 0.031 & 0.075 & 0.122 \\
$n$ & 408 & 166 & 90 & 152 \\
\hline
\end{tabular}

Note: Stayers were employed as RNs in consecutive years; switchers left nursing for another occupation; and quitters left employment. External Gap is the difference between the actual log wage and the predicted wage based on a regression of the control group of female workers. Internal Gap is based on a regression of RNs.

will result in only a 0.55 percent decrease in the probability that a nurse will leave for another occupation. Given the switching rate of about 3.3 percent, this implies about a 16.7 percent decrease in RNs leaving for other jobs. A similar increase in the intermal gap also results in a 0.55 percent decrease in the probability of switching occupations. The total effect of a one standard deviation increase in the control group residual is a 7.9 percent decrease in $\mathrm{RN}$ tumover (both leaving and quitting). As discussed previously, omitted worker-specific measures of skills will cause the coefficient to be biased toward zero, implying that these are lower-bound estimates of exit sensitivity to wages. Given that I am looking at relatively large samples over a long time period, it is assumed that these are long-run differences in tumover rates due to differences in wage structure and that the observed wage differentials have built up over time. If, however, it is assumed that these are short-run effects of a wage change, then RNs in the long run may be more sensitive than what is estimated.

It was hypothesized that RNs should not be overly sensitive to outside wages due to the high degree of occupation-specific training required. In occupations with less specific training, the wage gap should have a large impact on the decision to exit. The last two columns in Table 3 display the results of estimating the model for secretaries. ${ }^{7}$ The results indicate that secretaries, indeed, are much more sensitive to outside wages than are registered nurses. A one standard deviation increase in the wage 
Table 3

Multinomial Logit Estimates of the Probability of Staying Employed as an RN, Leaving Nursing for Another Occupation, or Quitting the Labor Market

\begin{tabular}{|c|c|c|c|c|c|c|}
\hline & \multicolumn{2}{|c|}{ Registered Nurses } & \multicolumn{2}{|c|}{ Registered Nurses } & \multicolumn{2}{|c|}{ Secretaries } \\
\hline & SWITCHER & QUITTER & SWITCHER & QUITTER & SWITCHER & QUITTER \\
\hline External Gap & $\begin{array}{c}-0.745 \\
(-4.603) \\
{[-0.013]}\end{array}$ & $\begin{array}{c}-0.068 \\
(0.383) \\
{[-0.000]}\end{array}$ & - & - & $\begin{array}{r}-0.730 \\
(-11.892) \\
{[-0.034]}\end{array}$ & $\begin{array}{c}-0.580 \\
(-9.873) \\
{[-0.012]}\end{array}$ \\
\hline Internal Gap & - & - & $\begin{array}{c}-0.790 \\
(-4.740) \\
{[-0.014]}\end{array}$ & $\begin{array}{c}-0.224 \\
(1.244) \\
{[-0.000]}\end{array}$ & - & - \\
\hline $\begin{array}{l}\text { Hospital } \\
\text { Employment }\end{array}$ & $\begin{array}{r}-2.157 \\
(-15.832) \\
{[-0.037]}\end{array}$ & $\begin{array}{c}-6.047 \\
(-9.826) \\
{[-0.004]}\end{array}$ & $\begin{array}{r}-2.284 \\
(-16.784) \\
{[-0.039]}\end{array}$ & $\begin{array}{c}-6.112 \\
(-9.694) \\
{[-0.004]}\end{array}$ & - & - \\
\hline Union Coverage & $\begin{array}{l}-1.255 \\
(-2.446) \\
{[-0.021]}\end{array}$ & $\begin{array}{c}-12.269 \\
(-0.068) \\
{[-0.008]}\end{array}$ & $\begin{array}{c}-1.253 \\
(-2.441) \\
{[-0.021]}\end{array}$ & $\begin{array}{c}-12.256 \\
(-0.068) \\
{[-0.007]}\end{array}$ & $\begin{array}{c}-0.520 \\
(-2.293) \\
{[-0.009]}\end{array}$ & $\begin{array}{c}-13.252 \\
(-0.082) \\
{[-0.302]}\end{array}$ \\
\hline $\begin{array}{l}\text { Public } \\
\text { Employment }\end{array}$ & $\begin{array}{c}0.035 \\
(0.259) \\
{[0.001]}\end{array}$ & $\begin{array}{c}-3.459 \\
(-6.815) \\
{[-0.002]}\end{array}$ & $\begin{array}{c}0.085 \\
(-0.632) \\
{[0.001]}\end{array}$ & $\begin{array}{l}-3.453 \\
(-6.801) \\
{[-0.002]}\end{array}$ & $\begin{array}{c}-0.112 \\
(-1.857) \\
{[-0.001]}\end{array}$ & $\begin{array}{c}-3.621 \\
(-16.037) \\
{[-0.083]}\end{array}$ \\
\hline Years of School & $\begin{array}{c}-0.202 \\
(-5.374) \\
{[-0.003]}\end{array}$ & $\begin{array}{c}-0.037 \\
(-1.008) \\
{[-0.000]}\end{array}$ & $\begin{array}{l}-0.152 \\
(-1.603) \\
{[-0.003]}\end{array}$ & $\begin{array}{c}-0.034 \\
(-1.011) \\
{[-0.000]}\end{array}$ & $\begin{array}{c}0.016 \\
(0.946) \\
{[0.001]}\end{array}$ & $\begin{array}{c}0.025 \\
(1.621) \\
{[0.001]}\end{array}$ \\
\hline $\begin{array}{l}\text { Married, } \\
\text { Spouse Present }\end{array}$ & $\begin{array}{c}-0.326 \\
(-1.862) \\
{[-0.006]}\end{array}$ & $\begin{array}{c}0.056 \\
(0.256) \\
{[0.000]}\end{array}$ & $\begin{array}{c}-0.327 \\
(-1.862) \\
{[-0.006]}\end{array}$ & $\begin{array}{c}0.060 \\
(0.276) \\
{[0.000]}\end{array}$ & $\begin{array}{c}-0.070 \\
(-0.994) \\
{[-0003]}\end{array}$ & $\begin{array}{c}0.148 \\
(2.058) \\
{[0.003]}\end{array}$ \\
\hline $\begin{array}{l}\text { Separated, } \\
\text { Divorced } \\
\text { or Widowed }\end{array}$ & $\begin{array}{c}0.050 \\
(0.247) \\
{[0.001]}\end{array}$ & $\begin{array}{c}-0.114 \\
(-0.458) \\
{[-0.000]}\end{array}$ & $\begin{array}{c}0.064 \\
(0.319) \\
{[0.001]}\end{array}$ & $\begin{array}{c}-0.105 \\
(-0.421) \\
{[-0.000]}\end{array}$ & $\begin{array}{c}0.274 \\
(3.207) \\
{[0.013]}\end{array}$ & $\begin{array}{c}-0.133 \\
(-1.460) \\
{[-0.003]}\end{array}$ \\
\hline Child 0-6 & $\begin{array}{c}-0.302 \\
(-1.707) \\
{[-0.005]}\end{array}$ & $\begin{array}{c}0.857 \\
(5.294) \\
{[0.001]}\end{array}$ & $\begin{array}{l}-0.303 \\
(-1.713) \\
{[-0.005]}\end{array}$ & $\begin{array}{l}0.886 \\
(5.289) \\
{[0.0006]}\end{array}$ & $\begin{array}{l}0.111 \\
(1.440) \\
{[0.004]}\end{array}$ & $\begin{array}{c}1.039 \\
(15.709) \\
{[0.024]}\end{array}$ \\
\hline Child 7-13 & $\begin{array}{c}-0.252 \\
(-1.490) \\
{[-0.004]}\end{array}$ & $\begin{array}{c}0.072 \\
(0.380) \\
{[0.000]}\end{array}$ & $\begin{array}{c}-0.250 \\
(-1.476) \\
{[-0.004]}\end{array}$ & $\begin{array}{c}0.065 \\
(0.341) \\
{[0.000]}\end{array}$ & $\begin{array}{c}-0.054 \\
(-0.674) \\
{[-0.003]}\end{array}$ & $\begin{array}{c}0.036 \\
(0.463) \\
{[0.001]}\end{array}$ \\
\hline Child $14-17$ & $\begin{array}{c}-0.102 \\
(-0.584) \\
{[-0.002]}\end{array}$ & $\begin{array}{c}-0.518 \\
(-2.498) \\
{[-0.000]}\end{array}$ & $\begin{array}{c}-0.098 \\
(-4.528) \\
{[-0.002]}\end{array}$ & $\begin{array}{c}-0.521 \\
(-2.507) \\
{[-0.000]}\end{array}$ & $\begin{array}{c}0.032 \\
(0.418) \\
{[0.001]}\end{array}$ & $\begin{array}{c}0.073 \\
(1.026) \\
{[0.002]}\end{array}$ \\
\hline Female & $\begin{array}{l}-0.568 \\
(-2.734) \\
{[-0.010]}\end{array}$ & $\begin{array}{c}0.921 \\
(2.415) \\
{[0.001]}\end{array}$ & $\begin{array}{c}-0.550 \\
(-2.651) \\
{[-0.009]}\end{array}$ & $\begin{array}{c}0.910 \\
(2.388) \\
{[0.001]}\end{array}$ & $\begin{array}{c}-0.234 \\
(-1.384) \\
{[-0.011]}\end{array}$ & $\begin{array}{c}-0.421 \\
(2.685) \\
{[-0.009]}\end{array}$ \\
\hline Chi Square & 1,8 & 905 & 1,81 & 086 & & 0.479 \\
\hline
\end{tabular}

Note: Data are from the 1983-1994 March supplements to the CPS. The logit coefficient is shown on the first line, $t$-statistics in parentheses. The numbers in brackets are the marginal impacts of a change in the right-hand-side variable on the probability of each employment status. External Gap is the difference between the actual log wage and the predicted wage based on a regression of the control group of female workers. Internal Gap is based on a regression of RNs. Child 0-6 is a dummy variable for the presence of children between the ages of 0 to 6 . Child 7-13 and Child 14-17 are defined sinilarly. The models also contain real family income, dummies for race (2), Hispanic origin, 5 year experience groups (5), metropolitan areas with 1983 population greater than 1 million, year (11), and region (8). 
gap (0.48) results in a 1.6 percent decrease in the probability that a secretary leaves for another occupation and a 0.58 percent decrease in the probability that a secretary leaves employment. The total effect of the increase in the wage gap would be to reduce turnover (switching and quitting) by 17 percent - more than twice the effect a similar increase would have on RNs. These results support my hypothesis that RN jobs require a high degree of occupation-specific training and, once attained, RNs are substantially less sensitive to outside wages. Altematively, secretarial jobs require much less occupation-specific training and secretaries are more mobile across occupations and, therefore, more sensitive to outside wages.

My findings are consistent with Link's conclusion that nurses have relatively small own-wage elasticities of hours supplied. I find that the relative wage has a small impact on the decision to change occupations, and an even smaller (insignificant) effect on the probability of leaving the labor market. Note that my findings do not imply that RNs are not responsive to wage changes by individual hospitals or employers. I show that there is a relatively small impact of relative wages on participation as an $\mathrm{RN}$ among all employers. An individual hospital will observe significant employment reduction (at least in the long run) if it lowers its wages relative to other employers of RNs.

While the relative wage is a significant determinant of the decision to remain in nursing, its omission does not appear to seriously bias other coefficient estimates. ${ }^{8}$ Hospital employment has a significantly negative impact on both the probability of switching occupations and quitting the labor market. Note that the substantially higher wage paid in hospitals is already accounted for in the internal gap measure. This implies that hospital RNs are less likely to exit, even after accounting for higher hospital wages. A possible explanation for this stronger attachment to the labor market is that hospitals hire and retain the most able RNs. If hospital RNs have an unusually strong comparative advantage in nursing as compared to RNs in non-hospital sectors, then hospital RNs are less likely to exit than non-hospital RNs. ${ }^{9}$ In addition, RNs tend to start their careers in hospitals with some later moving to non-hospital settings. Since young workers are least likely to leave the labor market, the impact of hospital employment in reducing quits is due, in part, to nurses with less actual experienced (controlling for potential experience) being employed in hospitals. Young RNs are also more likely to change occupations, however, and the negative effect of hospital employment on the probability of switching suggests that the effects of hospital employment are not purely age effects.

Even though union membership is estimated to have only a modest impact on the wages of RNs (Hirsch and Schumacher, forthcoming; Cain et al., 1981), Table 3 suggests that those covered by a union contract are significantly less likely to switch to altemative occupations, consistent with the presence of worker rents. Unions may provide higher non-wage benefits (e.g., pensions) to nurses not accounted for by wage data. My findings are consistent with economy-wide evidence that unions decrease quit rates, holding constant wages (Freeman, 1980). RNs in public employment are less likely to quit employment but are not less likely to change occupations 
than those employed in the private sector. As expected, the more experience or schooling an RN attains, the less likely he or she is to leave nursing for another occupation. Schooling has little effect on the probability of quitting employment, not surprising given the low variance in schooling among RNs.

Married RNs are less likely to switch occupations, and separated, divorced, or widowed RNs are less likely to quit employment. While married secretaries are significantly more likely to quit employment, marriage does not affect the probability of leaving employment for RNs. RNs with children between the ages of 0 and 6 years are more likely to quit employment and are less likely to change occupations than those with no children. Although standard errors are large, point estimates suggest that children make RNs substantially less mobile while they do not significantly affect the probability of switching for secretaries. These results are similar to Link's (1992), who finds that, when no children are in the home, the probability of participating in the labor market is substantially higher than when at least one child under age 6 is present. Not surprisingly female RNs are less likely to change occupations and more likely to quit employment than are the small number of male RNs.

\section{Conclusions}

I examine the occupational mobility of registered nurses. Relative earnings play a small but significant role in the decision to switch occupations. The relative wage has a negative (though insignificant) impact on the probability of leaving employment. That the estimated gap between the actual and alternative wage has a relatively small impact on the mobility of RNs is not surprising. First, my measure of the alternative wage suffers from an omitted ability problem which drives the relationship toward zero. Second, even if a more accurate measure of the outside wage were attained, I would still expect a relatively small impact of outside wages on the decision to leave nursing due to the relative nontransferability of nursing skills.

As direct evidence on this point I conduct a similar analysis on secretaries, an occupation where required training is much less occupation specific. Consistent with theory, while RNs are sensitive to outside opportunities, secretarial employees are substantially more sensitive to outside wages. These findings have implications for other occupations with occupation-specific (nontransferable) skills. As my results suggest, the more transferable are skills across occupation the more attention workers will give to alternative occupations.

Hospitals RNs are significantly more attached to the nursing labor market than those employed outside the hospital - even after accounting for higher hospital wages. Hospitals may attract the most qualified RNs (or those with a strong comparative advantage in nursing); moreover, Schumacher and Hirsch (1997) find that hospital employment is correlated with unmeasured ability. Also, while there is not a large union wage differential among RNs, these results suggest that unionized RNs are significantly more attached to the labor market, consistent with worker rents. 
My results are consistent with the long periods of nursing shortages reported in the 1980s. As employers bid up wages to attract RNs into the market, the supply was very slow to respond since rising relative wages did not attract currently licensed RNs into the market. Similarly, the findings have implications for the apparent decline in RN demand experienced over the past few years. My results suggest that exit rates should not rise dramatically among RNs as relative RN wages decrease.

\section{NOTES}

*The author appreciates the helpful comments of Barry Hirsch, David Macpherson, and Leola Ross.

${ }^{1}$ Since the CPS is household specific, individuals who changed households between March and their corresponding outgoing month (April, May, or June), were not able to be matched and are not included in the data set.

${ }^{2}$ The SSRN asks if you were employed in nursing one year prior to the date of the survey.

${ }^{3}$ For the control regressions I use the monthly CPS outgoing rotation group files for the years 1983 through 1994. The sample sizes for these regressions were 269,628 for the control group of non-health workers, and 34,806 registered nurses.

${ }^{4}$ The regression used to calculate the RN predicted wage was estimated using the entire CPS ORG crosssectional data set. The mean residual for all groups, therefore, need not equal zero.

${ }^{5}$ The predicted wage is intended to represent the unobserved wage of the nurse if he or she were employed elsewhere. This measure of the reservation wage is estimated by using the difference between the actual and predicted wage. These values are measured with sampling error and therefore the standard errors associated with the logit equation are incorrect and in general are biased toward zero (Murphy and Topel, 1985). This is because the parameter estimates are obtained using a predicted value for a right-hand-side variable, and additional imprecision not accounted for is introduced into the model.

${ }^{6}$ Other than the variables included in Table 3, the model includes real family income, dummy variables for race (2) Hispanic origin, 5 year experience categories (5), metropolitan areas with 1983 populations greater than 1 million, year (11), and region (8).

${ }^{7}$ Secretaries are defined as the following three Census occupations: secretaries, stenographers, and typists. There are 31,418 secretaries in the sample: 5.8 percent switched to another occupation and 7.0 percent quit employment.

${ }^{8}$ In results not shown I estimate the model excluding the wage gap measures. The coefficients and marginal effects are virtually identical for all the remaining right-hand-side variables.

${ }^{9}$ Schumacher and Hirsch (1997) examine the hospital wage differential among RNs and conclude that it is in part due to hospitals attracting higher quality RNs and in part due to compensating wage differentials for more demanding working conditions. 


\section{REFERENCES}

Brider, Patricia. "Huge Job-Projections Shock Health Professionals." American Journal of Nursing 96 (January 1996a): 61, 64.

"Enrollment Boom Ends as Job Hunts Lengthen." American Joumal of Nursing 96 (February 1996b): 61-62.

Cain, Glen G., Brian E. Becker, Catherine G. McLaughlin, and Albert E. Schwenk. "The Effect of Unions on Wages in Hospitals." In Research in Labor Economics, edited by Ronald Ehrenberg. Vol. 4. Greenwich, Conn. JAI Press, 1981, pp.191-320.

Freeman, Richard B. "The Exit Voice Tradeoff in the Labor Market: Unionism, Job Tenure, Quits, and Separations." Quarterly Journal of Economics 94 (June 1980): 643-73.

Hirsch, Barry T., and Edward J. Schumacher. "Union Wages, Rents, and Skills, in Health Care Labor Markets." Joumal of Labor Research (forthcoming).

Link, Charles R. “Labor Supply Behavior of Registered Nurses: Female Labor Supply in the Future?” In Research in Labor Economics, edited by Ronald Ehrenberg. Vol. 13. Greenwich, Conn.: JAI Press, 1992, pp. 287-320.

, and Russell F. Settle. "A Simultaneous-Equation Model of Labor Supply, Fertility and Earnings of Married Women: The Case of Registered Nurses." Southern Economic Journal 47 (April 1981a): $977-89$.

"Wage Incentives and Married Professional Nurses: A Case of Backward Bending Supply?" Economic Inquiry 19 (January 198lb): 144-56.

"Labor Supply Responses of Married Professional Nurses: New Evidence." Joumal of Human Resources 14 (Spring 1979): 256-66.

Murphy, Kevin M., and Robert H. Topel. "Estimation and Inference in Two-Step Econometric Models." Joumal of Business and Economic Statistics 3 (October 1985): 370-79.

Parker, Carl, and Bill Rickman. "Economic Determinants of the Labor Force Withdrawal of Registered Nurses." Journal of Economics and Finance 19 (Spring 1995): 17-26.

Phillips, V.L. "Nurses' Labor Supply: Participation, Hours of Work and Discontinuities in the Supply Function." Journal of Health Economics 14 (December 1995): 567-82.

Polivka, Anne E. and Jennifer M. Rothgeb. "Overhauling the Current Population Survey: Redesigning the Questionnaire.” Monthly Labor Review 116 (September 1993): 10-28.

Schumacher, Edward J. "Relative Wages and the Returns to Education in the Labor Market for Registered Nurses." In Research in Labor Economics, Solomon Polachek, ed. Greenwich, Conn.: JAI Press, forthcoming.

, and Barry T. Hirsch. "Compensating Differentials and Unmeasured Ability: Why Do Hospitals Pay More?" Industrial and Labor Relations Review 50 (July 1997): 557-79. 